DOI

\author{
${ }^{\odot}$ C. В. Врублевська
}

Запорізъкий державний медичний університет

\title{
ОСОБЛИВОСТІ ПЕРВИННОЇ ПРОФІЛАКТИКИ АТОПІЧНИХ ЗАХВОРЮВАНЬ У ДІТЕЙ ПІВДЕННО-СХІДНОГО РЕГІОНУ УКРАЇНИ
}

ОСОБЛИВОСТІ ПЕРВИННОЇ ПРОФІЛАКТИКИ АТОПІЧНИХ ЗАХВОРЮВАНЬ У ДІТЕЙ ПІВДЕННО-СХІДНОГО РЕГІОНУ УКРАЇнИ. В останніх зарубіжних джерелах зроблено спроби запропонувати методи і способи захисту від можливої сенсибілізації, однак немає єдиного підходу. Розглядаються можливості імунної модуляції і розвитку толерантності до харчових продуктів шляхом елімінації потенційних алергенів. Ми пропонуємо комплекс профілактичних заходів, адаптований до нашого регіону, які шляхом імунної модуляції сприяли розвитку толерантності до харчових продуктів і також до можливих алергенів.

ОСОБЕННОСТИ ПЕРВИЧНОЙ ПРОФИЛАКТИКИ АТОПИЧЕСКИХ ЗАБОЛЕВАНИЙ У ДЕТЕЙ ЮГО-ВОСТОЧНОГО РЕГИОНА УКРАИНЫ. В последних зарубежных источниках предприняты попытки предложить методы и способы защиты от возможной сенсибилизации, однако нет единого подхода. Рассматриваются возможности иммунной модуляции и развития толерантности к пищевым продуктам путем элиминации потенциальных аллергенов. Мы предлагаем комплекс просилактических мероприятий, адаптированный к нашему региону, которые путем иммунной модуляции способствовали развитию толерантности к пищевым продуктам и также к возможным аллергенам.

PECULIARITIES OF PRIMARY PROPHYLAXIS OF ATOPIC DISEASES IN CHILDREN OF SOUTH-EASTERN REGION OF UKRAINE. Attempts to suggest methods and ways to protect against the probable allergy made in the last sensitization in the foreign sources, but there is no single approach. Opportunities of the immune modulation and the development of tolerance to foods treated by elimination of potential allergens. We offer a range of preventive measures adapted to our region who have immune modulation by contributing to the development of tolerance to foods and other possible allergens.

Ключові слова: атопія, діти, профрілактика.

Ключевые слова: атопия, дети, профилактика.

Key words: atopy, children, prevention.

ВстУП. Останнім часом зросла роль техногенного впливу на організм людини, що зумовлює високий рівень атопічних захворювань серед дитячого населення. Прояви алергії реєструються в період новонародженості у 13,2 \% малюків [5, 7]. Лідерами виявилися регіони 3 високою техногенною напругою: Донецька, Запорізька, Дніпропетровська, Харківська області й м. Київ. В останніх зарубіжних джерелах зроблено спроби запропонувати методи і способи профрілактики ймовірної сенсибілізації до алергенів, проте немає системного єдиного підходу. Існують можливості імунної модуляції і формування толерантності до продуктів харчування шляхом елімінації потенційних алергенів. Інша гіпотеза - ранній контакт алергенів та шлунково-кишкового тракту швидше повинен запобігати розвитку алергії, а не активувати її.

Активно розробляються методи визначення спадкової схильності, які заклали фрундамент предиктивної медицини. Предиктивна медицина - один із напрямків сучасної молекулярної науки, яка вивчає можливість передбачення формування захворювання у дитини на основі дослідження індивідуальних геномів пацієнтів [2]. «Тривалий час медицина намагалася лікувати хвороби. Зараз її головна мета - запобігти фрормуванню захворювань. Для цього необхідно навчитися передбачати їх ймовірність. Перший крок у цьому напрямку вже зроблено - предиктивна медицина народилася» (Дж. Доссе, 1977). Одним з основних епігенетичних фракторів просрілактики розвитку атопічних захворювань у дітей $є$ грудне вигодовування новонародженої дитини та дієта жінкигодувальниці, раціональний догляд за немовлям [1-3]. 3 необхідністю гіпоалергенної дієти для новонароджених 3 групи ризику до появи клінічних симптомів погоджуються не всі вчені [2].

Первинна профрілактика алергії у дітей з групи ризику в постнатальний період, за даними ВОО3, повинна включати:

а) організацію грудного вигодовування, якщо немає можливості - застосування частково гідролізованих високоадаптованих сумішей;

б) заборону коров'ячого молока та сумішей із сої;

в) відмову від раннього введення прикорму (до 6-ти місяців);

г) обмеження ранніх контактів дитини $з$ домашніми, промисловими, інфрекційними та іншими агентами й алергенами: запобігання контактам із домашніми тваринами; зниження гострої респіраторної та гельмінтнопаразитарної захворюваності; виключення пасивного тютюнокуріння [1-6].

Застосування вимог до гіпоалергенних профрілактичних сумішей (ESPACI й ESPGHAN, 2005): 1) профрілактична суміш повинна сприяти «зниженню ризику розвитку алергії до білків коров'ячого молока», надано об'єктивні наукові дані, які підтверджують її ефективність; 2) вміст імунореактивного білка в суміші повинен бути меншим 1 \%; 3) суміш має бути протипоказана дітям 3 підтвердженою алергією до білків коров'ячого молока за 
відсутності клінічних доказів ефективності суміші у таких дітей [1-4, 6, 8].

Враховуючи недостатню кількість досліджень, присвячених впливу профрілактичних щеплень на розвиток алергічних захворювань, це питання також доцільно згадати в даній статті. Відсутні добре задокументовані докази негативного ефекту, що виникає через вакцинацію і сприяє розвитку алергії. 3 іншого боку, є окремі свідчення на користь того, що проведення вакцинації може знизити ризик розвитку алергії (рівень доказовості - С) [7].

Метою роботи було дослідити спектр причинновагомих алергенів у дітей раннього віку м. Запоріжжя та Запорізької області порівняно з даними по Україні та Європі й на основі отриманих даних розробити адаптований до нашого регіону комплекс профрілактичних засобів для немовлят з обтяженим алергологічним анамнезом.

МАТЕРІАЛИ ТА МЕТОДИ. Користуючись результатами дослідження загального і специфічних IgE та специфрічних IgG4 у 623 дітей віком 0-3 років Запорізької, Одеської, Херсонської областей, ми вдосконалили комплекс елімінаційних профрілактичних засобів, запропонований ВОО3, шляхом видалення тільки тих облігатних алергенів, які частіше зустрічаються в дітей з атопічним дерматитом Південно-Східної України. Рівні загального і специфрічних IgE та специфрічних IgG4 визначали методом імуноферментного аналізу за допомогою ІФА-аналізатора «Immulyte 2000» та набору реактивів фрірми «Siemens» (Німеччина) на базі сертифікованої лабораторії «ДІАсервіс».

РЕЗУЛЬТАТИ ДОСЛІДЖЕННЯ ТА ЇХ ОБГОВОРЕННЯ. Серед 623 обстежених дітей до 3-х років із клінічними проявами алергічних реакцій тільки 239 (38,36 \%) мали $\lg$ Е-залежний тип алергічних реакцій, у 61 дитини (9,79\%) виявили підвищені рівні специфічних $\operatorname{lgG} 4$, у 323 немовлят (51,84 \%) загальний та специфічні IgE, еозинофрільний катіонний білок були в межах вікової норми.

Досліджено поступове зменшення рівня гіперсенсибілізації до причинно-вагомих алергенів у малюків 3 $\lg$ Е-залежним механізмом захворювання відповідно до зниження рівня забруднення навколишнього середовища (рис. 1): у м. Запоріжжі - дуже високий - 17,04к 2 2,3кЕ/л - IV клас - до нативних алергенів курячого яйця (13F1-G,

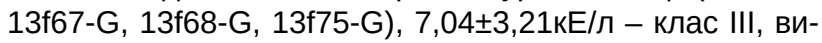
сокий - до протеїнів коров'ячого молока (13f2-G, 13f293295-G); на морському узбережжі - в 7,4 раза нижчий, ніж у м. Запоріжжі, та у 4,85 раза нижчий, ніж у районних центрах Запорізької області. Рівень сенсибілізації до компонентів курячого яйця найнижчий у сільській місцевості

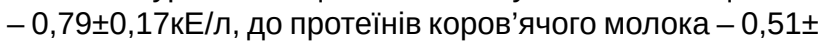
0,07кE/л, клас I - низький, що у 20,56 раза менше, ніж у м. Запоріжжі.

Аналогічно зменшувався рівень специфрічного IgG4 відповідно до зниження екологічної напруги - у м. Запоріжжі - 43721 246 МЕ/мл - до нативних алергенів яйця і коров'ячого молока; на чорноморському узбережжі - в 1,68 раза нижчий, ніж у м. Запоріжжі, та у 4,99 раза нижчий, ніж на узбережжі Азовського моря; найнижчий рівень

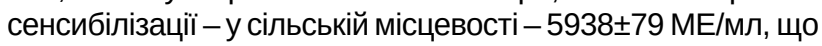
у 7,36 раза менше, ніж у м. Запоріжжі (рис. 2). Отримані результати підтверджують сенсибілізувальний ефект ксенобіотиків - промислових виробництв, напівсинтетичних продуктів харчування тощо.

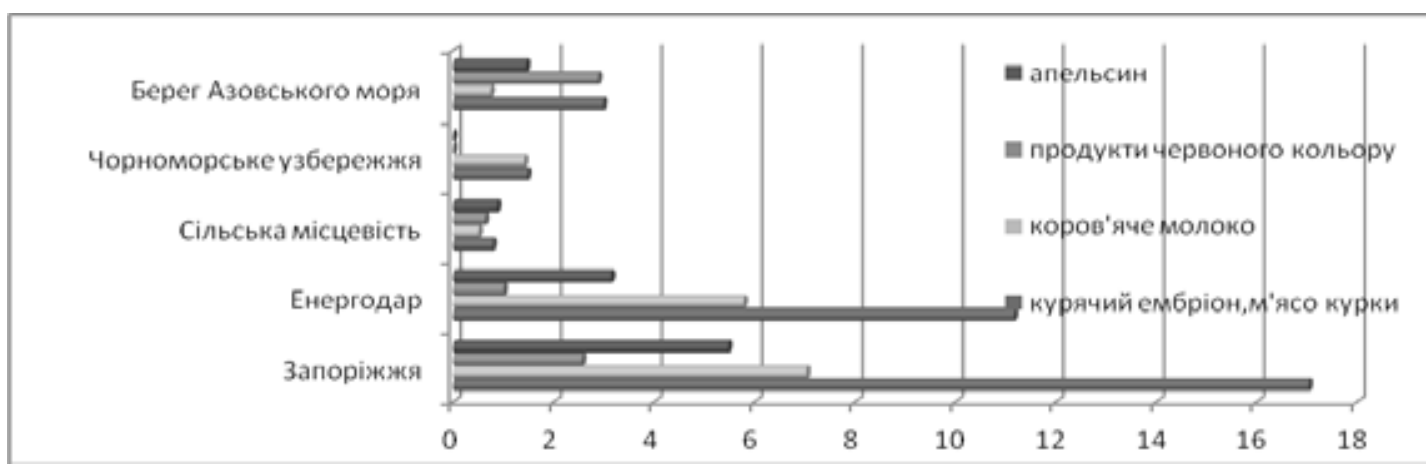
(кЕ/л).

Рис. 1. Рівень специфічного IgЕ до харчових алергенів у дітей раннього віку з клінічними проявами атопічного дерматиту

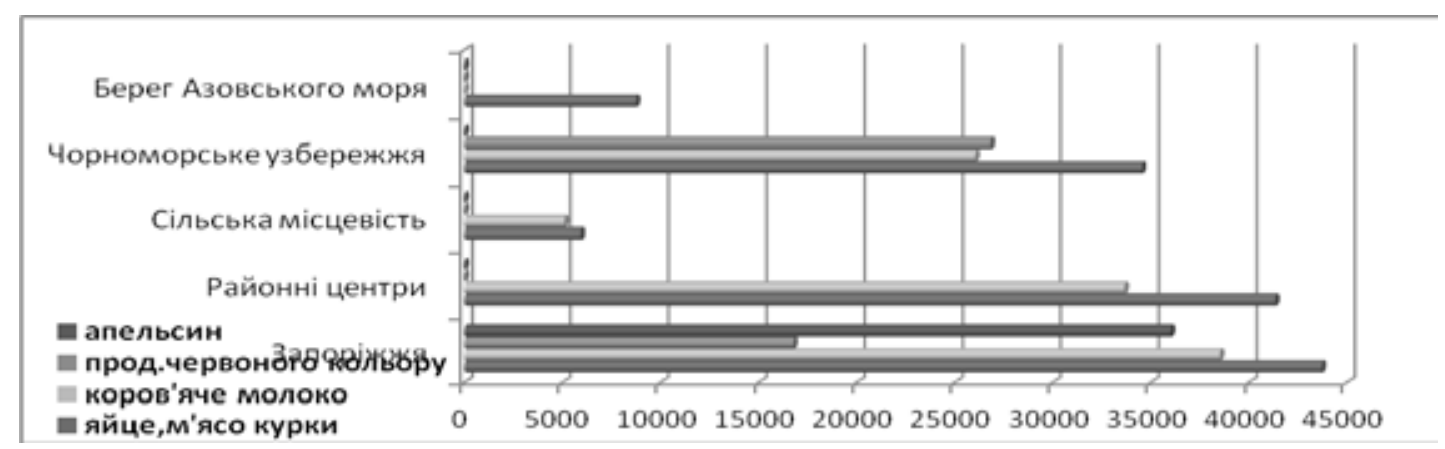
(кЕ/л).

Рис. 2. Рівень специфічного IgG4 до харчових алергенів у дітей раннього віку з клінічними проявами атопічного дерматиту 
До риби (М-паральбумін), арахісу (перехресна алергія з бобовими рослинами: зелений горох, соя, боби, люпин і сочевиця), злаків (глютен - гліадин), пшениці, кукурудзи, рису та гречки сенсибілізації серед 623 дітей піддослідної групи не було виявлено.

Найбільш вагоме значення у фрормуванні атопічних захворювань серед інгаляційних алергенів мають (рис. 3) епідермальні алергени домашніх тварин (е1-5): специяічний IgE - у 9,8 раза вищий, ніж до грибкових алергенів $(16,67 \pm 5,82$ проти $1,7 \pm 0,7$ кЕ/л), та у 2,78 раза вищий, ніж до бур'янів. Рівень специфрічного $\lg$ д до побутових алергенів (d1-3, ех6) нижчий, ніж до епідермальних алергенів домашніх тварин, у 7,57 раза $(16,67 \pm 5,85$ проти $2,21 \pm 0,17 \mathrm{kE} / л)$. Гіперсенсибілізацію до нативних грибкових алергенів (m2, m3, m6) виявлено тільки в поєднанні 3 гіперчутливістю до побутових алергенів у дітей, старших 2-х років, - жителів м. Запоріжжя та Азовського узбереж-

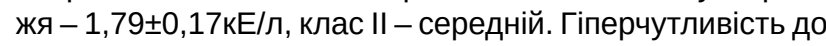
бур'янів виявлено вже на 2-му році життя - 12,02+1,3кЕ/л. Максимальною була кількість дітей з IgG4-залежним механізмом гіперчутливості до інгаляційних алергенів, відзначено найбільш поширений спектр сенсибілізації до побутових і епідермальних алергенів домашніх тварин (переважно кішки).

Спектр сенсибілізації в дітей з уже сорормованим атопічним дерматитом вказує на високу частоту використання у дієті вагітних жінок і матерів-годувальниць продуктів коров'ячого молока, відсутність розуміння необхідності обмеження облігатних алергенів у дієті малюків, житлових приміщеннях, застосування тільки якісних, спеціально призначених для дитячого віку засобів гігієни, що мають зволожувальний ефект на шкіру малюків. Насторожує висока частота догодовування новонароджених з групи ризику в перші дні життя сумішами на основі коров'ячого молока (частота догодовування сумішами у пологовому будинку - 58 \%), яке, ймовірно, не завжди проводять за абсолютними показаннями. Цей фрактор ризику є регульованим.

Тому первинна профрілактика алергії в дітей у постнатальний період, на наш погляд, повинна враховувати результати дослідження етіологічних чинників атопії у дітей раннього віку в регіоні проживання. У дітей Європейського регіону на першому році життя про-

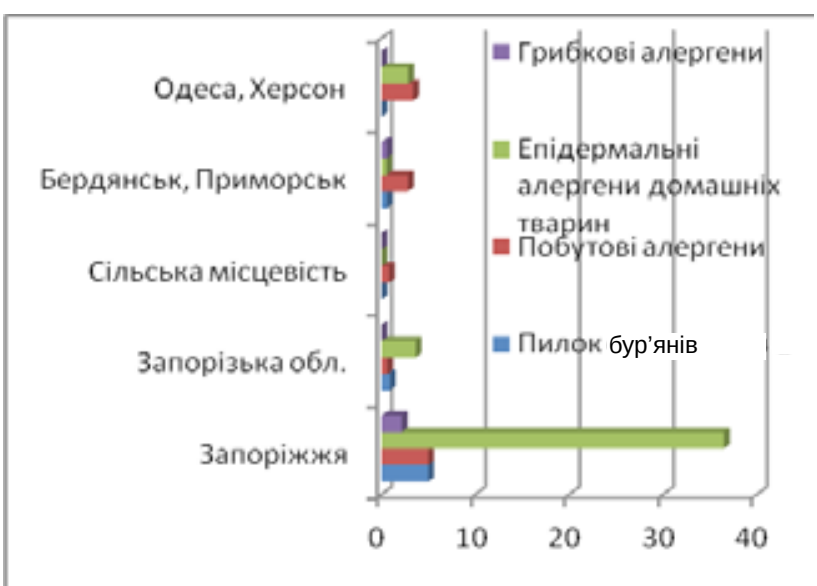

відне місце серед харчових алергенів посідають білки коров'ячого молока, яйця, що відповідає отриманим даним. Проте до риби (М-паральбумін), арахісу (перехресна алергія з бобовими рослинами: зелений горох, соя, боби, люпин і сочевиця), злаків (глютен - гліадин), пшениці, кукурудзи, рису та гречки сенсибілізації не було виявлено. Вищезазначені продукти не потрібно виключати 3 раціону новонароджених дітей Південно-Східної України. Необхідно сорормувати імунну толерантність організму дітей шляхом більш повільного поступового введення цих продуктів в їх раціон. До того ж, ми вважаємо, що раннє введення до прикорму риби (крім червоних видів) $€$ одним із засобів профрілактики харчової алергії в дітей, бо перш за все омега-3 жирні кислоти риб'ячого жиру пригнічують синтез PGE2. PGE2 зменшує вироблення Т-лімфоцитами IFN- $\alpha$, що приводить до збільшення продукування В-лімфоцитами специфічних IgE і розвитку атопії. Таким чином, регулярне споживання риби протягом перших 12 місяців життя дозволить знизити ризик сенсибілізації до риби в дітей раннього віку.

Заборона споживання дитиною до 3-х років продуктів коров'ячого молока, на наш погляд, не доцільна. Ми повинні сорормувати шляхом імунної модуляції толерантність до продуктів коров'ячого молока, коригуючи харчування дітей: при неможливості грудного вигодовування - використання сумішей на основі спочатку повного гідролізату білків коров'ячого молока (казеїну і сироваткових протеїнів) та зниженого вмісту лактози 3 переходом на частковий гідролізат (тільки казеїну). При відсутності клінічних проявів алергії - після 4-х місяців - поступовий, протягом 1 місяця, перехід на звичайну високоадаптовану суміш на основі коров'ячого молока, але на фоні обов'язкового використання пребіотиків з метою покращення метаболізму лактози у кишечнику.

Якщо перехід на штучне вигодовування відбувається на 4-му місяці життя - використання часткового гідролізату білків зі зниженим вмістом лактози з поступовим, протягом 2-х тижнів, переходом на кисломолочну суміш тієї ж фрірми.

При грудному вигодовуванні обмежене використання продуктів коров'ячого молока ми пропонуємо реалізувати шляхом введення у раціон кисломолочних продуктів (кефір і сир) після 8-го місяця життя, введення телятини

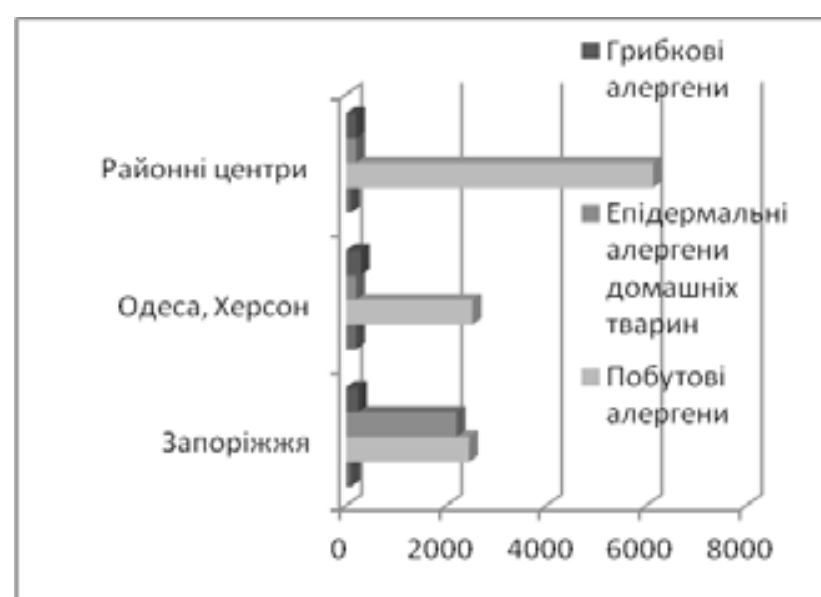

Рис. 3. Рівень специсрічних IgE (зліва) та специфічних IgG4 (справа) до інгаляційних алергенів у дітей з атопічним дерматитом залежно від регіону (кЕ/л). 
і яловичини на 2-му році життя. Як перший м'ясний прикорм необхідно споживати нежирну свинину, кролятину, індичатину, м'ясо нутрії.

Використання досвіду середземноморської дієти, яка містить великий обсяг свіжих фрруктів і овочів, на нашу думку, також дозволить зменшити ризик розвитку в нашому регіоні бронхіальної астми та інших клінічних проявів пилкової сенсибілізації.

Відмову від сумішей на основі сої ми вважаємо раціональною, бо L-протеїни та набір амінокислот тваринного молока за умови заміни на суміші на основі повного гідролізату протеїну з обмеженням вмісту лактози більш фрізіологічні для немовлят, у тому числі з обтяженим атопічним анамнезом.

Використання вимог до гіпоалергенних профрілактичних сумішей (ESPACI й ESPGHAN, 2005) абсолютно доцільне, їх необхідно враховувати при формуванні індивідуального комплексу засобів первинної профрілактики атопії у немовлят.

Ми вважаємо, що вакцинацію дітей згідно зі стандартною або індивідуальною схемою необхідно проводити, бо вона не збільшує ризику розвитку атопічних захворювань у дітей віком один рік. Інтенсивний контакт з бактеріальними антигенами знижує можливість перемикання Th1-клітинної імунної відповіді 3 переважанням ії̈ над Th2-клітинною в напрямку збалансованого співвідношення Th1- і Th2-відповідей та є проективним фрактором, що попереджує фрормування атопії в дітей раннього віку [3]. Зменшення «мікробного навантаження» призводить до розвитку алергії з більшою ймовірністю [1-8]. Результати ретроспективного дослідження когорти дітей, народжених у Манітобі (Канада) в 1995 році, показали негативний зв'язок між затримкою вакцинації першою дозою цільноклітинної ДКС (дисртерія-правець-кашлюк) в дитинств й розвитком БА; зв'язок цей був встановлений у дітей, яким вакцинацію проводили із затримкою введення всіх перших трьох доз. Механізм цього явища вимагає подальшого вивчення.

Ми вважаємо необхідним, щоб усі діти, в тому числі 3 групи високого ризику розвитку алергії, були вакциновані згідно з Календарем щеплень. Проте для запобігання формуванню сенсибілізації до компонентів вакцини ми пропонуємо використовувати тільки високоочищені ліофілізовані вакцини на основі рекомбінантної ДНК, інактивованих та очищених анатоксинів. Їх введення необхідно супроводжувати короткочасним призначенням антигістамінних засобів, потрібно витримувати

\section{СПИСОК ЛІТЕРАТУРИ}

1. Martorell A. M. The predictive value of specific immunoglobulin $E$ levels in serum for the outcome of the development of tolerance in cow's mil kallergy / A. M. Martorell //J.Allergol. Immunopathol. - Vol. 36, № 6. - P. 325-330.

2. Ramesh S. Food Allergy Over view in Children / S. Ramesh // J. Clin. Rev. Allergylmmunol. - 2014. - Vol. 8. P. 23-33.

3. Muraro A. EAACI food allergy and anaphylaxis guidelines. Primary prevention of food allergy / A. Muraro // J.Allergy. - 2014. - Vol. 69(5). - P. 590-601.

4. Погоджувальний документ Асоціації дитячих алергологів та імунологів Росії // Первинна профрілактика алергії у дітей. - М., 2010. - С. 15-26. 2-тижневу перерву після інфекційних захворювань, не проводити щеплення під час епідемії та пандемії грипу, обов'язково перед щепленням досліджувати клітинний склад перисреричної крові з метою виключення продромального періоду інфекційних захворювань, виключення десріцитних захворювань крові, які знижують фрормування антиінфекційного імунітету, що дозволяє визначити несприятливі фрактори і скорегувати графрік вакцинації для досягнення максимального ефекту.

ВисновКИ. 1. Серед немовлят з атопічним механізмом реагування максимальним був рівень гіперсенсибілізації до харчових алергенів (переважно до протеїнів курячого яйця (34,48 \%) і коров'ячого молока (25\%)) та інгаляційних алергенів (переважно до епідермальних алергенів домашніх тварин (28,7\%) і побутових алергенів (29 \%)). Створення гіпосенсибілізувального ефекту до вищезазначених облігатних алергенів дозволить попередити розвиток атопії в дітей раннього віку.

2. Рекомендації ВООЗ щодо елімінації потенційних чинників алергії у новонароджених необхідно адаптувати до Запорізького регіону: якщо до риби (М-паральбумін), арахісу (перехресна алергія з бобовими рослинами: зелений горох, соя, боби, люпин і сочевиця), злаків (глютен гліадин), пшениці, кукурудзи, рису та гречки сенсибілізації не було виявлено, вищезазначені продукти не повинні виключатися з раціону дітей раннього віку.

3. Необхідно, щоб усі діти, в тому числі з групи високого ризику розвитку алергії, були вакциновані згідно 3 Календарем щеплень (рівень доказовості - D) [7].

4. Раннє формування імунної толерантності до харчових продуктів, у тому числі потенційних алергенів, шляхом поступового повільного введення їх у харчовий раціон немовлят дозволить зменшити рівень сенсибілізації, попередити ії фрормування та знизити рівень захворюваності на атопію в дітей.

ПЕРСПЕКТИВИ ПОДАЛЬШИХ ДОСЛІДЖЕНЬ. ВИзначення рівня специфічних IgE периферичної крові матерів під час загострення атопічного процесу та показників аналогічних специфічних $\lg$ в в пуповинній крові їх новонароджених дітей і визначення кореляційних зв'язків між отриманими даними буде наступним етапом наших досліджень. Дослідження, що плануються, дозволять довести наявність сенсибілізації плода під час загострення атопічного захворювання вагітної жінки та необхідність призначення засобів первинної профрілактики алергічних захворювань у дітей вже на антенатальному етапі.

5. Охотнікова О. М. Профілактика алергії у дітей: сучасні можливості та перспективи / О. М. Охотнікова // Дитячий лікар. - 2011. - № 4. - С. 26-35.

6. Костроміна В. П. Етапи профрілактики алергійних захворювань у дітей / В. П. Костроміна, В. О. Стриж // Дитячий лікар. - № 2. - С. 48-50.

7. Беш Л. В. Профілактика алергічних захворювань у дітей: наскільки можливою вона є сьогодні? / Л. В. Беш // Дитячий лікар. - 2009. - № 1. - С. 7-13.

8. Казначеєва Л. Ф. Профрілактика алергічних захворювань у дітей групи ризику : керівництво для лікарів / Л. Ф. Казначеєва. - М., 2009. - 90 с.

Отримано 02.02.16 